\title{
ІНФОРМАЦІЙНА ОЦІНКА ТА КОРЕКЦІЯ ЗАБЕЗПЕЧЕННЯ ОПТИМАЛЬНОЇ РОЗУМОВОЇ ПРАЦЕЗДАТНОСТІ ЛЮДИНИ В УМОВАХ ВПЛИВУ ВІКОВОЇ Інволюції
}

\author{
Н. В. Харковлюк-Балакіна, Ю. П. Горго \\ ДУ "Інститут геронтології ім. Д. Ф. Чеботарьова НАМН України" \\ Національний технічний університет України «КПІ» ${ }^{1}$
}

\begin{abstract}
Розроблено алгоритм реалізації інформаційної технології оцінки та корекції розумової працездатності людини в умовах впливу вікової інволюції для оптимізації професійної діяльності.
\end{abstract}

Ключові слова: інформаційна оцінка забезпечення оптимальної розумової працездатності, алгоритм реалізації інформаційної технології оцінки та корекції розумової працездатності людини, інформаційні технології.

\section{ИНФОРМАЦИОННАЯ ОЦЕНКА И КОРРЕКЦИЯ ОБЕСПЕЧЕНИЯ ОПТИМАЛЬНОЙ УМСТВЕННОЙ РАБОТОСПОСОБНОСТИ ЧЕЛОВЕКА В УСЛОВИЯХ ВЛИЯНИЯ ВОЗРАСТНОЙ ИНВОЛЮЦИИ}

\author{
Н. В. Харковлюк-Балакина, Ю. П. Горго ${ }^{1}$ \\ ГУ "Институт геронтологии им. Д. Ф. Чеботарева НАМН Украины" \\ Национальный технический университет Украины «КПИ»"
}

\begin{abstract}
Принципиальные отличия предложенного в работе информационного подхода заключаются в разработке алгоритма реализации информационной технологии оценки и коррекции обеспечения оптимальной работоспособности человека в условиях умственного утомления.
\end{abstract}

Ключевые слова: информационная оценка обеспечения оптимальной умственной работоспособности, алгоритм реализации информационной технологии оценки и коррекции умственной работоспособности человека, информационные технологии.

\section{INFORMATION EVALUATION AND CORRECTION OF O PTIMAL MENTAL PERFORMANCE OF PERSON UNDER THE INFLUENCE OF AGE INVOLUTION}

\author{
N. V. Kharkovliuk-Balakina, Yu. P. Horho ${ }^{1}$ \\ SI "Institute of Gerontology by D. F. Chebotariov of NAMS Ukraine" \\ National Technical University of Ukraine "Kiev Polytechnic Institute"

\begin{abstract}
The principal difference in information approach proposed in this work is the development of algorithm implementation of information technology evaluation and correction of optimal mental performance of person under conditions of mental fatigue.
\end{abstract}

Key words: integral evaluation to ensure optimal mental performance, algorithm implementation of information technology evaluation and correction of optimal mental performance of person, information technology.

Вступ. Еволюція розвитку науково-технічних досягнень людства максимально наблизила суспільство до впроваджень інформативних технологій, однак проблема впливу людського чинника не стає менш глобальною та перетинається з багатьма сферами професійної діяльності, у зв'язку з чим особливого значення набуває проблема розробки та удоско- налення засобів контролю стану здоров'я персоналу і ефективності реалізації їх професійних навичок.

На разі життєдіяльність сучасної людини не у повній мірі відповідає потребам організму у руховій активності. Окремим чинником ризику багатьох патологічних змін в осіб розумової праці виступають реакції гіпокінетичного синдрому, серед яких зниження

(C) Н. В. Харковлюк-Балакіна, Ю. П. Горго 
функціональних резервів серцево-судинної та дихальної систем, порушення опорно-рухового апарату на тлі тенденції зростання загальної маси тіла тощо, що дає підставу для пошуку ефективних засобів своєчасної діагностики донозологічних станів людини та корекції працездатності в умовах розумового навантаження.

Вирішення проблеми професійного довголіття базується на вивченні адаптаційних можливостей організму людини. Сучасні дослідження професійної працездатності осіб розумової праці перетинаються 3 науковими проблемами, пов'язаними з оцінкою функціональних станів людини, прогнозуванням ефективності трудової діяльності та працездатності [1], інформаційними технологіями адаптивного управління працездатністю та оцінкою здоров'я людини [2, 3]. Однак у контексті пошуку засобів інтегральної оцінки розумової працездатності людини необхідно відзначити проблему обмеженості комплексних методик тестування на тлі відсутності вікових критеріїв оцінки оптимального забезпечення працездатності людини.

Актуальність даної роботи обумовлена спектром напрямів фундаментальних здобутків, резюмуючим результатом яких виступає висновок про відсутність єдиного шаблону вікових змін психофізіологічних характеристик та професійних здібностей людини, що цілком обгрунтовує необхідність доповнення науко- вого розуміння проблеми професійного старіння та пошуку об'єктивних засобів оцінки та корекції працездатності людини в умовах розумового навантаження із застосуванням інформаційний підходів.

Мета роботи - реалізація інформаційного підходу до інтегральної оцінки та корекції працездатності людини в умовах розумового навантаження.

Матеріали та методи. Інформаційний підхід був обгрунтований розвитком сучасних інформаційних технологій, методологія яких дозволяє використовувати усі доступні засоби аналізу та синтезу отриманих даних для усвідомлення та отримання нової інформації про об'єкт дослідження. Інформаційна оцінка розумової працездатності (РП) людини базувалася на використанні ряду методів інформаційних технологій, розроблених на базі Міжнародного науково-навчального центру інформаційних технологій та систем НАН і МОН України: метод інформаційногоструктурного моделювання, метод інфотомування, метод уніфікованого нормування різноякісної інформації, метод побудови узагальнених оцінок [2].

Вибір інформативних показників забезпечення оптимальної РП був обгрунтований результатами дослідження вікової динаміки психофізіологічних та вегетативних характеристик професійної адаптації у 345 осіб різних видів розумової праці віком 21-74 роки, розподілених на три вікові групи (табл. 1).

Таблиця 1. Граничні межі діапазону вікової норми ${ }_{4}\left(\mathrm{X}_{\text {шах }}^{\mathrm{H}}, \mathrm{X}_{\text {шіп7 }}^{\mathrm{H}}\right)$ й повного діапазону змін $\left(\mathrm{X}_{\text {шах }}, \mathrm{X}_{\text {шт }}\right)$ показників забезпечення оптимальної РП (X) у чоловіків (ч) та жінок (ж) різних вікових груп

\begin{tabular}{|c|c|c|c|c|c|c|c|c|}
\hline \multirow[t]{2}{*}{$\begin{array}{c}\text { Показник, } \\
X\end{array}$} & \multicolumn{2}{|c|}{$\begin{array}{c}\text { Повний діапазон } \\
\text { змін }\end{array}$} & \multicolumn{2}{|c|}{$\begin{array}{c}\text { Перший період зрілого } \\
\text { віку: } \\
22-35 \text { (ч), 21-35 (ж) років }\end{array}$} & \multicolumn{2}{|c|}{\begin{tabular}{|c|} 
Другий період зрілого \\
віку: \\
36-60 (ч), 36-55 (ж) років
\end{tabular}} & \multicolumn{2}{|c|}{$\begin{array}{c}\text { Літній вік: } \\
\text { 61-74 (ч), } \\
\text { 56-74 (ж) років }\end{array}$} \\
\hline & $\overline{X_{\min }}$ & $X_{\max }$ & $X_{\min }^{H}$ & $X_{\max }^{H}$ & $X_{\text {min }}^{\mathrm{H}}$ & $X_{\max }^{\mathrm{H}}$ & $X_{\min }^{\mathrm{H}}$ & $X_{\max }^{\mathrm{H}}$ \\
\hline ЧСС, хв. -1 & 12 & 290 & 50 & 85 & 55 & 90 & 55 & 95 \\
\hline CAT, мм pm. $\mathrm{cm}$. & 51 & 292 & 90 & 130 & 95 & 140 & 95 & 135 \\
\hline ДАТ, мм рm. $\mathrm{cm}$. & 30 & 170 & 60 & 80 & 65 & 90 & 60 & 85 \\
\hline ЖЄЛ, л (ч) & 0,5 & 7,0 & 3,3 & 7 & 2,8 & 7 & 1,8 & 7 \\
\hline ЖЄЛ, л (ж) & 0,5 & 7,0 & 2,7 & 7 & 2,2 & 7 & 1,6 & 7 \\
\hline ЗДвд, с (ч) & 15 & 180 & 85 & 180 & 58 & 180 & 32 & 180 \\
\hline ЗДвд, с (ж) & 15 & 180 & 55 & 180 & 38 & 180 & 22 & 180 \\
\hline ЗДвид, с (ч) & 5 & 100 & 55 & 100 & 38 & 100 & 18 & 100 \\
\hline ЗДвид, с (ж) & 5 & 100 & 45 & 100 & 28 & 100 & 16 & 100 \\
\hline СБ, с (ч) & 1 & 180 & 58 & 180 & 30 & 180 & 15 & 180 \\
\hline СБ, с (ж) & 1 & 180 & 38 & 180 & 28 & 180 & 10 & 180 \\
\hline ТТ, кільк. рухів & 30 & 220 & 180 & 220 & 160 & 220 & 120 & 220 \\
\hline ОКСП, $\%$ & 0 & 100 & 83 & 100 & 67 & 100 & 50 & 100 \\
\hline $\mathrm{CU}, \mathrm{c}$ & 0 & 60 & 0 & 5 & 0 & 8 & 0 & 10 \\
\hline ОКЗП, \% & 0 & 100 & 83 & 100 & 58 & 100 & 33 & 100 \\
\hline $\mathrm{Ne}, \%$ & 0 & 100 & 95 & 100 & 85 & 100 & 80 & 100 \\
\hline RRNN, Mc & 100 & 1200 & 500 & 700 & 400 & 750 & 350 & 800 \\
\hline SDNN, мc & 10 & 150 & 55 & 90 & 45 & 85 & 35 & 80 \\
\hline
\end{tabular}


Для вивчення впливу вікової інволюції на загальний фізичний стан обстежуваних використовували фізіологічні показники за методикою визначення функціонального віку та темпу старіння людини, розробленою на базі лабораторії професійно-трудової реабілітації ДУ "Інститут геронтології ім. Д. Ф. Чеботарьова НАМН України" [4].

Статистична обробка даних здійснювалася 3 використанням методів описової (середнє арифметичне, стандартна похибка середнього арифметичного, середньоквадратичне відхилення) та індуктивної математичної статистики (параметричний t-критерій Ст'юдента) за допомогою компю'терних програм «STATISTICA 6» та «Microsoft Excel 2000».

Результати та їх обговорення. Для розробки способу інтегральної оцінки РП людини, згідно з методологією інформаційних технологій, яка грунтується на тріаді "дані - інформація - знання" [2], було розроблено структуру оцінки забезпечення оптимальної РП людини в умовах впливу вікової інволюції (рис. 1). Ієрархічний розподіл на чотири рівні, згідно 3 методом інфотомування [2], проводили евристичним шляхом. Інтегральна оцінка РП людини формувалася із оцінок наступних компонентів РП: психофізіологічне й вегетативне забезпечення РП та темп старіння людини (рис. 1), які відображено на четвертому рівні структури. На третьому рівні відокремлено складові забезпечення оптимальної РП: інтелектуальна й емоційна складова забезпечення РП та загальний фізичний стан людини, які формуються з оцінок поточного стану систем (другий рівень). Перший рівень структури представлено фізіологічними та психофізіологічними показниками забезпечення оптимальної РП людини, переведеними в уніфіковану форму (рис. 1). Вибір корелят психофізіологічного та вегетативного забезпечення РП людини був обгрунтований результатами лонгітудинальних досліджень закордонних авторів [5], що резюмують фундаментальну концепцію узгодженості різних функціональних станів із серцевим ритмом.

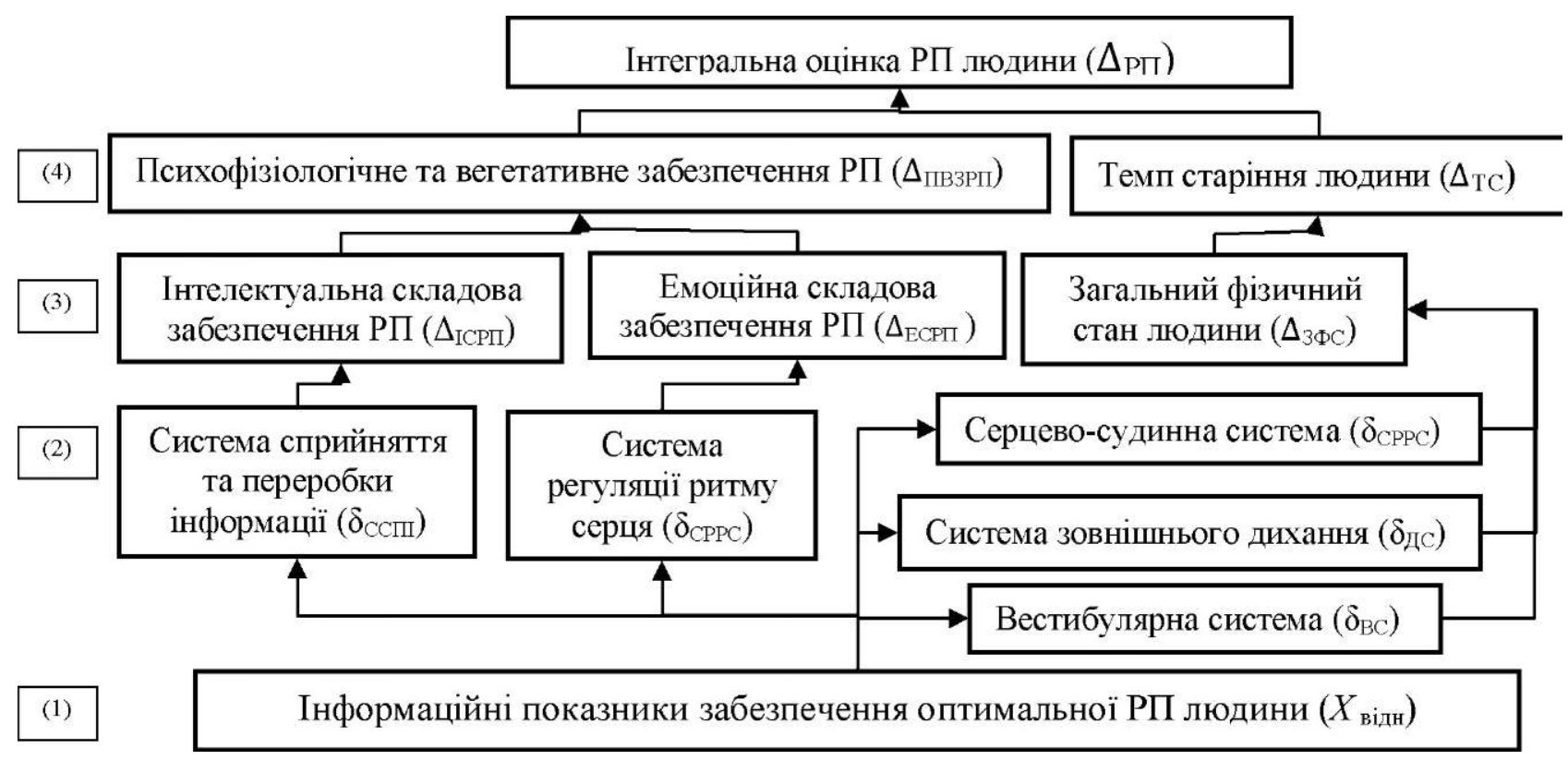

Puc. 1. Структура оцінки забезпечення оптимальної розумової працездатності (РП) людини в умовах впливу вікової інволюції ( ${ }^{1} 234$ - рівні ієрархії).

Отже, за результатами аналізу вікової динаміки психофізіологічних та вегетативних характеристик РП, інформативними (вікозалежними) показниками забезпечення оптимальної РП людини було відібрано наступні параметри: загальна кількість рухів кисті за 30 с при проведенні тепінг-тесту (ТT, кількість рухів), за яким оцінюється витривалість нервової системи; показники стану психофізіологічних функцій: помилка сприйняття часового інтервалу 30 с (СЧ, с); обсяг короткочасної зорової пам'яті
(ОКЗП, \%) - кількість відтворених цифр із таблиці з дванадцятьма випадковими числами від 11 до 99, які протягом 30 с необхідно запам'ятати; обсяг короткочасної слухової пам'яті (ОКСП, \%) - кількість цифр, відтворених у зворотному порядку, із дев'яти запропонованих символів при вербальному завданні; надійність уваги (Ne, \%) - розраховується як результат співвідношення кількості правильно виконаних завдань на увагу до загальної кількості завдань, помножений на 100 \%; середня тривалість кардіо- 
інтервалів, $\quad$ мc) та їх середнє квадратичне відхилення ( $\aleph^{\wedge}$ Д $\left.м с\right)$.

3 позиції адаптаційно-регуляторної теорії, висунутої В. В. Фролькісом (1981), старіння - це не тільки просте згасання обміну та функцій, але і мобілізація пристосувальних механізмів "вітаукту"; отже, загальний фізичний стан людини виступає вагомим фактором лімітування працездатності, оскільки пов'язаний з загальними закономірностями вікових змін. Разом 3 тим, специфіка трудової діяльності осіб розумової праці пов'язана з впливом гіпокінезії як одного з факторів ризику патологічних змін функціонального стану серцево-судинної й дихальної системи та опорнорухового апарату, отже, серцево-судинна, дихальна та вестибулярна системи представлено на другому рівні ієрархічної структури оцінки РП (рис. 1). Інформативними показниками темпу старіння людини [4] було визначено наступні показники: частота серцевих скорочень у спокої (ЧСС, хв. ${ }^{-1}$ ); систолічний артеріальний тиск (САТ, ммрт. cm.), діастолічний артеріальний тиск (ДАТ, мм pm. cm.), життєва ємність легенів (ЖЕЛ, л), тривалість затримки дихання на вдиху (ЗДвд, c), тривалість затримки дихання на видиху (ЗДвид, с) та статичне балансування (СБ, с) .

При розробці способу інтегральної оцінки РП людини застосовувався метод уніфікації різноякісної інформації [2] для переведення виділених інформа- тивних показників $(X)$ в інформаційні $\left(\mathrm{X}_{\text {відн}}\right)$, тобто уніфіковані, за віковою нормою. Визначення граничних меж діапазону вікової норми ( $\left.\mathrm{X}_{\text {max }} \mathrm{X}_{\mathrm{T}}\right)$ й повного діапазону змін $\left(X_{\max }, X_{m m^{\prime}}\right)$ кожного інформативного показника $(X)$ у чоловіків (ч) та жінок (ж) різних вікових груп (табл. 1) було проведено експертним шляхом за аналізом результатів проведеної психофізіологічної діагностики професійної адаптації осіб розумової праці та за даними літератури.

Таким чином, реалізація способу інтегральної оцінки РП людини, представлена на рисунку 2, базується на послідовності наступних дій: вимірювання показників $(X)$; їх уніфікація засобом представлення у єдиному діапазоні змін $\left(0<\mathrm{X}_{\text {відн }} £ 1\right)$, відповідно до вікової групи обстежуваного (табл. 1); ієрархічна згортка уніфікованих показників $\left(\mathrm{X}_{\text {щн }}\right)$ засобом лінійно виважених сум (згідно побудованої ієрархічної структури оцінки (рис. 1) для отримання узагальнених оцінок стану систем забезпечення РП (д), з відповідними ваговими коефіцієнтами, представленими у таблиці 2; подальша ієрархічна згортка для отримання узагальнених оцінок складових забезпечення оптимальної РП (Д РП (Д єнтами (табл. 2). У підсумку отримується інтегральна оцінка РП (Дрп), розрахована відповідно до вікової групи обстежуваного (рис. 2).

Таблиця 2. Значення вагових коефіцієнтів (ВК) для уніфікованих показників $\left(X_{\text {eidi }}\right)$ та узагальнених оцінок $(5$, А) при розрахунку інтегральної оцінки РП у чоловіків (ч) та жінок (ж) різних вікових груп

\begin{tabular}{|c|c|c|c|c|}
\hline $\begin{array}{c}\text { Уніфіковані } \\
\text { показники }\left(X_{\text {відн }}\right) \\
\text { та узагальнені } \\
\text { оцінки }(\delta, \Delta)\end{array}$ & $\mathrm{BK}$ & $\begin{array}{l}\text { Перший період зрілого } \\
\text { віку: } \\
\text { 22-35 (ч), 21-35 (ж) років }\end{array}$ & $\begin{array}{c}\text { Другий період зрілого } \\
\text { віку: } \\
\text { 36-60 (ч), 36-55 (ж) років }\end{array}$ & $\begin{array}{c}\text { Літній вік: } \\
\text { 61-74 (ч), } \\
\text { 56-74 (ж) років }\end{array}$ \\
\hline 1 & 2 & 3 & 4 & 5 \\
\hline $\mathrm{YCC}_{\mathrm{BiдH}}$ & $\alpha_{1}$ & 0,20 & 0,23 & 0,30 \\
\hline $\mathrm{CAT}_{\text {відн }}$ & $\alpha_{2}$ & 0,43 & 0,43 & 0,33 \\
\hline ДАТ $_{\text {відн }}$ & $\alpha_{3}$ & 0,37 & 0,33 & 0,37 \\
\hline ЖЕЛ $Л_{\text {відн }}$ ч & $\alpha_{4}$ & 0,29 & 0,15 & 0,17 \\
\hline ЖЕЛ ${ }_{\text {відн }}$ Ж & $\alpha_{4}$ & 0,22 & 0,20 & 0,25 \\
\hline ЗДв відн $_{\text {с }}$ & $\alpha_{5}$ & 0,34 & 0,38 & 0,44 \\
\hline ЗДвд відн ж & $\alpha_{5}$ & 0,41 & 0,39 & 0,41 \\
\hline ЗДвид & $\alpha_{6}$ & 0,37 & 0,46 & 0,40 \\
\hline ЗДвид & $\alpha_{6}$ & 0,38 & 0,42 & 0,35 \\
\hline $\mathrm{Cb}_{\text {Biдн }} \mathbf{Y}$ & $\alpha_{7}$ & 0,28 & 0,34 & 0,38 \\
\hline $\mathrm{CБ}_{\text {вілн }} ж$ & $\alpha_{7}$ & 0,32 & 0,34 & 0,34 \\
\hline $\mathrm{TT}_{\text {відн }}$ & $\alpha_{8}$ & 0,36 & 0,34 & 0,26 \\
\hline $\mathrm{OKCП}_{\text {відн }}$ & $\alpha_{9}$ & 0,23 & 0,20 & 0,24 \\
\hline $\mathrm{CY}_{\mathrm{BizH}}$ & $\alpha_{10}$ & 0,08 & 0,09 & 0,10 \\
\hline ОКЗ $\Pi_{\text {відн }}$ & $\alpha_{11}$ & 0,19 & 0,22 & 0,24 \\
\hline$N e_{\text {відн }}$ & $\alpha_{12}$ & 0,15 & 0,15 & 0,15 \\
\hline$R R N N_{\text {відн }}$ & $\alpha_{13}$ & 0,24 & 0,30 & 0,31 \\
\hline$S D N N_{\text {відн }}$ & $\alpha_{14}$ & 0,47 & 0,33 & 0,26 \\
\hline
\end{tabular}


Продовження табл. 2

\begin{tabular}{|l|c|c|c|c|}
\hline \multicolumn{1}{|c|}{1} & 2 & 3 & 4 & 5 \\
\hline$\delta_{\mathrm{CCC}}$ & $\beta_{1}$ & 0,60 & 0,60 & 0,60 \\
\hline$\delta_{\text {ДC }}$ & $\beta_{2}$ & 0,25 & 0,25 & 0,25 \\
\hline$\delta_{\mathrm{BC}}$ & $\beta_{3}$ & 0,15 & 0,15 & 0,15 \\
\hline$\Delta_{\mathrm{ICP} I}$ & $\gamma_{1}$ & 0,65 & 0,65 & 0,65 \\
\hline$\Delta_{\mathrm{ECР}}$ & $\gamma_{2}$ & 0,35 & 0,35 & 0,35 \\
\hline$\Delta_{\Pi \text { ПЗП }}$ & $\mu_{1}$ & 0,70 & 0,70 & 0,70 \\
\hline$\Delta_{\mathrm{TC}}$ & $\mu_{2}$ & 0,30 & 0,30 & 0,30 \\
\hline
\end{tabular}

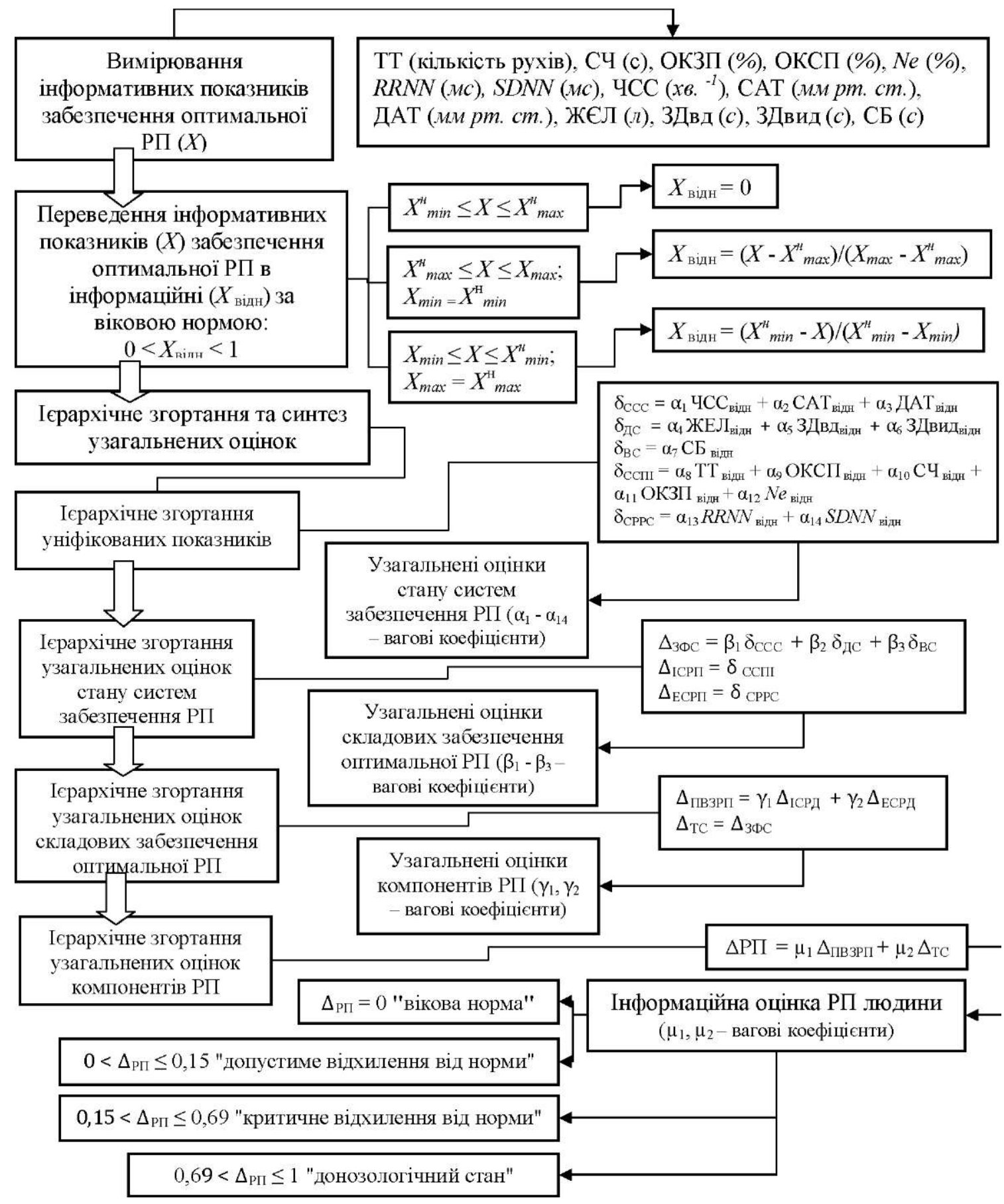

Puc. 2. Схема реалізації способу інтегральної оцінки розумової працездатності (РП) людини. 

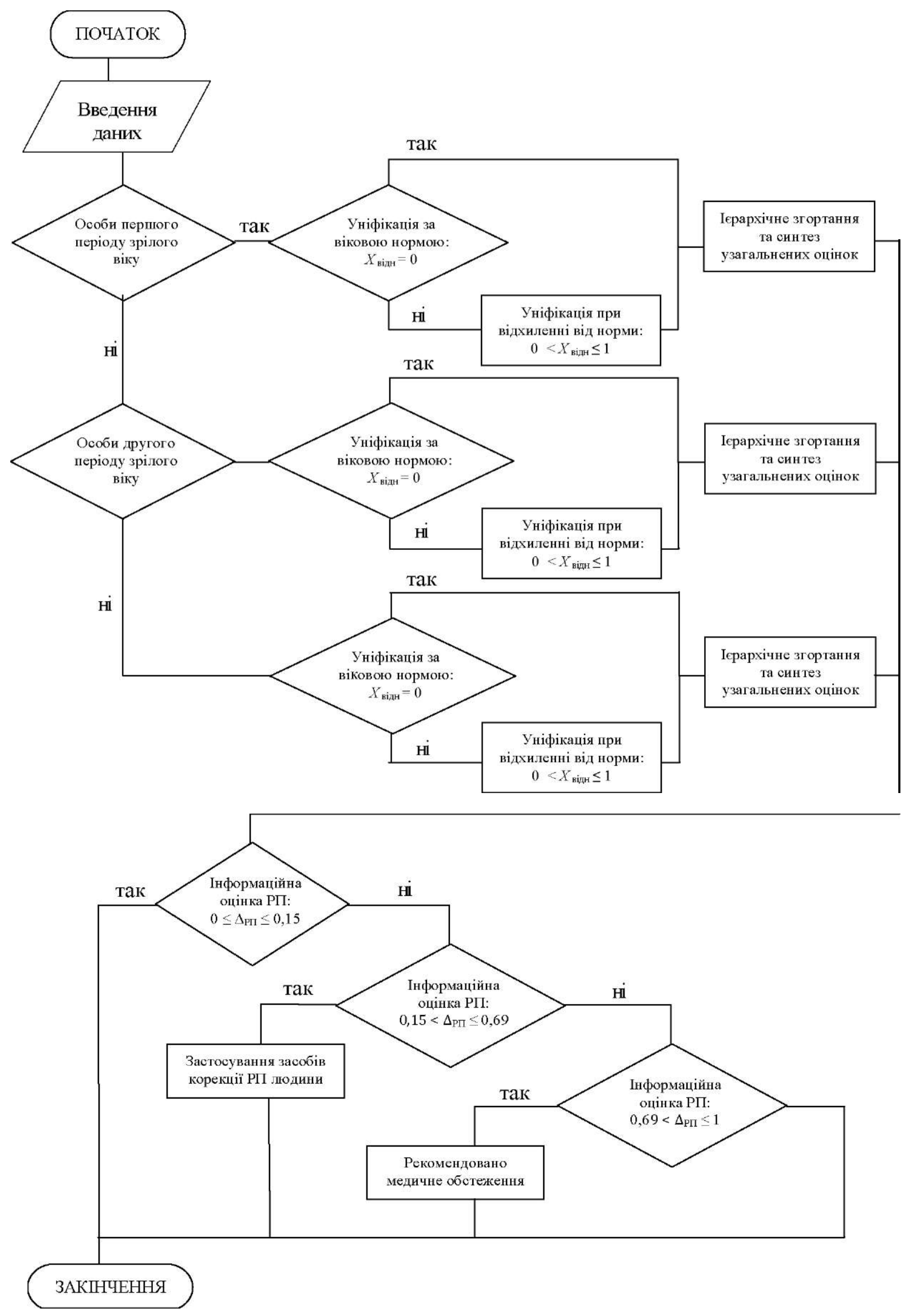

Puc. 3. Алгоритм реалізації інформаційної технології оцінки та корекції розумової працездатності (РП) людини. 
Вербальне трактування отриманих інформаційних оцінок грунтується на фізіолого-вікових змінах оптимального функціонування організму людини та згідно 3 ергономічним підходом характеризує професійне здоров'я за наступними станами - вікова норма й відхилення від вікової норми та донозологічний стан.

Оскільки багаточисельні наукові дані доводять, що на забезпечення оптимальної РП людини в умовах розумового навантаження суттєво впливає загальний фізичний стан людини та вегетативний статус, то для корекції та оптимізації РП у межах вікової норми був використаний комплекс фізичних вправ у режимі робочого дня, як канал зворотного зв'язку (згідно кібернетичного підходу, запропонованого Ю. П. Горго, 2010).

Алгоритм реалізації інформаційної технології оцінки та корекції РП людини представлено на рисунку 3. Стан «критичного відхилення від вікової норми» (діапазон значень: $0,15<Д_{\text {рп }}<0,69$ ) характеризується початком системної відповіді організму людини на зміни функціонального робочого стану у бік динамічного неузгодження, отже наслідком зни-

\section{Література}

1. Навакатікян А. О. Фізіологія і гігієна розумової праці / А. О. Навакатікян, В. В. Крижанівська, В. В. Кальниш. - К. : Здоров'я, 1987. - $152 \mathrm{c.}$

2. Інформаційні технології в біології та медицині : курс лекцій / Гриценко В. І., Котова А. Б., Вовк М. І. [та ін.] - К. : Наук. думка, 2007. - 382 с.

3. Основні вимоги до структури типових медичних інформаційних систем в управлінні охороною здоров'я / О. П. Мінцер, М. В. Банчук, І. А. Ярменчук, С. О. Дяченко // Медична інформатика та інженерія. - 2011. - $\mathrm{N}^{\circ}$ 2. - С. 34-35. ження адаптаційного потенціалу виступає збільшення фізіологічної ціни виконуваної роботи, що потребує змін умов праці та введення засобів корекції РП. «Донозологічний стан» (діапазон значень: $0,69<Д_{\text {рп }}<1$ ) відображає виражене перенапруження адаптаційних механізмів, пов'язаних із ризиком виникнення деструктивних функціональних станів та потребує застосування диференційної медико-біологічної діагностики.

Висновки. 1. Запропонований спосіб інтегральної оцінки розумової працездатності людини з використанням методів інформаційних технологій дозволяє отримати прогностичну оцінку забезпечення оптимального рівня працездатності людини в умовах впливу вікової інволюції та доповнює існуючі наукові дані моніторингу розумової працездатності, пов'язані 3 віко-стажовими тенденціями професійного старіння.

2. Розроблений алгоритм інформаційної технології оцінки та корекції працездатності людини при розумових навантаженнях надає можливості діагностики донозологічних станів людини в умовах розумового навантаження та обгрунтовує своєчасне застосування засобів професійно-трудової реабілітації.

4. Спосіб визначення функціонального віку організму людини / Решетюк А. Л., Поляков А. А., Коробейніков Г. В. [та ін.] // Патент № 14734, Україна, МПК А61 В5/02/ Інститут геронтології АМН України.

5. The Coherent Heart: Heart-Brain Interactions, Psychophysiological Coherence, and the Emergence of System / R. McCraty, M. Atkinson, D. Tomasino, R. Bradley T. - Wide Order. - 2004. [Електр. pесурс]. - Режим доступу: http:// store.heartmath.org/seientific-monographs/cogerent-heart. 